\title{
Comparison of the excretory capacities of erythropoietin and U-74389G concerning serum creatinine levels
}

\section{Comparación de las capacidades excretoras de eritropoyetina y $U-74389 G$ respecto a los niveles de creatinina sérica}

Constantinos Tsompos ${ }^{1}$ Constantinos Panoulis ${ }^{2}$ Konstantinos Toutouzas ${ }^{3}$ Aggeliki Triantafyllou ${ }^{4}$ George Zografos ${ }^{5}$ Apostolos Papalois ${ }^{6}$

${ }^{1}$ Consultant A, Department of Obstetrics \& Gynecology, Mesologi County Hospital, Etoloakarnania, Greece

2 Assistant Professor, Department of Obstetrics \& Gynecology, Aretaieion Hospital, Athens University, Attiki, Greece

${ }^{3}$ Assistant Professor, Department of Surgery, Ippokrateion General Hospital, Athens University, Attiki, Greece

${ }^{4}$ Associate Professor, Department of Biologic Chemistry, Athens University, Attiki, Greece

5 Professor, Department of Surgery, Ippokrateion General Hospital, Athens University, Attiki, Greece

${ }^{6}$ Director, Experimental Research Centre ELPEN Pharmaceuticals, S.A. Inc., Co., Attiki, Greece
Address for correspondence Constantinos Tsompos, Consultant A, Department of Obstetrics \& Gynecology, Mesologi County Hospital, Etoloakarnania, Greece (e-mail: Tsomposconstantinos@gmail.com).

\section{Abstract \\ Keywords \\ - ischemia \\ - erythropoietin \\ - U-74389G \\ - creatinine \\ - reperfusion}

Introduction This study compared the excretory effects, the erythropoietin (Epo) and antioxidant drug U-74389G exert on serum creatinine levels through kidneys. 2 preliminary studies were used for this purpose including respectively one drug used in a renal ischemia-reperfusion (IR) protocol of an animal model. The preliminary studies are part of the present work. The subjects were pretreated in preliminary studies but the results of the same subjects were simply compared in the current work. Materials and methods The serum creatinine levels were evaluated at the 60th reperfusion min (for groups $\mathrm{A}, \mathrm{C}$ and $\mathrm{E}$ ) and at the 120th reperfusion min (for groups B, $D$ and $F$ ) after IR in the 60 rats. Groups $A$ and $B$ received no drugs, rats from groups $C$ and $D$ were administered with Epo, whereas rats from groups $E$ and $F$ were administered with U-74389G.

Results The first preliminary study recommended a non-significant excretory effect of Epo $(p$-value $=0.4430>0.05)$ than placebo for serum creatinine levels. The second preliminary study proved a very significant excretory effect of U-74389G ( $p$-value $=0.0005$ $<0.05$ ) than placebo for serum creatinine levels. These 2 studies were co-evaluated since they came from the same experimental setting. The outcome of the co-evaluation was that received December 29, 2016 accepted March 13, 2017 published online January 10, 2018
DOI https://doi.org/ 10.1016/j.uroco.2017.03.006. ISSN 0120-789X. eISSN 2027-0119.
Copyright (c) 2018, Sociedad Colombiana License terms de Urología. Publicado por Thieme Revinter Publicações Ltda., Rio de Janeiro, Brazil. Todos los derechos reservados. 


\section{Resumen}

\section{Palabras clave}

- isquemia

- eritropoyetina

- U-74389G

- creatinina

- reperfusión
U-74389G has at least 5-fold significant excretory action ( $p$-value $=0.0000<0.05$ ) than Epo for serum creatinine levels.

Conclusions The U-74389G presents surprising effective excretory potencies for serum creatinine levels maybe of great importance in hemodialysis patients.

Introducción Este estudio comparó los efectos excretores que la eritropoyetina (Epo) y el fármaco antioxidante U-74389G ejercen sobre los niveles de creatinina sérica a través de los riñones. Se utilizaron 2 estudios preliminares incluyendo, respectivamente, un fármaco utilizado en una rata protocolo de reperfusión de isquemia renal. Los estudios preliminares son parte del presente trabajo. Los sujetos fueron pretratados en estudios preliminares, pero los resultados de los mismos sujetos fueron comparados simplemente en el trabajo actual.

Materiales y métodos Se evaluaron los niveles de creatinina sérica en la 60 . $^{\text {a }}$ reperfusión en minutos (para los grupos $A, C$ y E) y en la 120. a reperfusión en minutos (para los grupos B, D y F) después de isquemia renal en las 60 ratas. Los grupos A y B no recibieron fármacos, a las ratas de los grupos $C$ y $D$ se les administró Epo, mientras que las ratas de los grupos E y $\mathrm{F}$ se les administró U-74389G.

Resultados El primer estudio preliminar recomendó un efecto excretor no significativo de la Epo (valor $p=0,4430>0,05$ ) comparado con el placebo para los niveles de creatinina sérica. El segundo estudio preliminar demostró un efecto excretor muy significativo del U-74389G (valor $\mathrm{p}=0,0005<0,05$ ) comparado con el placebo para los niveles de creatinina sérica. Estos 2 estudios fueron coevaluados, ya que procedían del mismo entorno experimental. El resultado fue que el U-74389G tiene una acción excretora significativa de al menos 5 veces $(p=0,0000<0,05)$ la Epo para los niveles de creatinina sérica.

Conclusiones El U-74389G presenta sorprendentes potencias excretoras efectivas para los niveles de creatinina sérica, tal vez de gran importancia en pacientes en hemodiálisis.

\section{Introduction}

The short-term excretory ${ }^{1}$ action of U-74389G is significant ( $p$-value $=0.0005<0.05)$ than placebo for serum creatinine levels. U-74389G is a novel antioxidant factor. It implicates just only 255 known biomedical studies at present. $18.03 \%$ of these studies concern tissue ischemia and reperfusion (IR) experiments. The promising effect of U-74389G in tissue protection has been noted in these IR studies. U-74389G or also known as 21-[4-(2,6-di-1-pyrrolidinyl-4-pyrimidinyl)1-piperazinyl]-pregna-1,4,9(11)-triene-3,20-dione maleate salt is an antioxidant which prevents both arachidonic acid-induced and iron-dependent lipid peroxidation. It protects against IR injury in animal heart, liver and kidney models. These membrane-associating antioxidants are particularly effective in preventing permeability changes in brain microvascular endothelial cells monolayers. However, the excretory capacity of U-74389G gets more comprehensible whether is compared with the same capacity of a standard known drug. Erythropoietin (Epo) is one of the more well studied and popular drug in hemodialysis (HD) medicine. However, the excretory ${ }^{2}$ action of Epo was proved non-significant $(p$-value $=0.4430>0.05)$ than placebo for serum creatinine levels. Actually, Epo implicates over 29,309 known biomedical studies at present. 3.46\% at least of these studies concern tissue IR experiments. Although Epo is frequently used in HD medicine, just few related comparative drug reports were found in bibliography.

The special aim of this experimental work was to compare the excretory effects of U-74389G and Epo on a rat model and mainly in a renal IR protocol concerning the serum creatinine levels. The American Diabetes Association uses new more reliable renal function markers such as the eGFR accurately automatically calculated by serum creatinine concentration, sex, age, weight and race, without a 24-h urine collection; and the new overestimating standardized isotope dilution mass spectrometry method (SIDMS) which measures low creatinine values for example $0.7 \mathrm{mg} / \mathrm{dl}$. However, the classic serum creatinine level measurement is fundamental and the odds ratios found here may not differ for respective ratios of eGFR and SIDMS.

\section{Materials and methods}

\section{Animal preparation}

The Vet licenses of the research were provided under 3693/ 12-11-2010 and 14/10-1-2012 decisions. The granting company and the place of the experiment are mentioned in 
related references. ${ }^{1,2}$ Appropriate humanistic care was adopted for the Albino female Wistar rats. 7 days preexperimental normal housing included ad libitum diet for rats. Non-stop intra-experimental general anesthesia, oxygen supply, electrocardiogram and acidometry were provided. Euthanasia excluded the post-experimental survival of animals. Rats 16-18 weeks old were randomly delivered to six (6) groups $(n=10)$. The introductory stage of $45 \mathrm{~min}$ ischemia was common for all the 6 groups. Furthermore, the IR protocols were individualized for every group as following reperfusion: for $60 \mathrm{~min}$ (group A); for $120 \mathrm{~min}$ (group B); immediate Epo intravenous (IV) administration and reperfusion for $60 \mathrm{~min}$ (group C); immediate Epo IV administration and reperfusion for $120 \mathrm{~min}$ (group D); immediate U-74389G IV administration and reperfusion for 60 min (group E); immediate U-74389G IV administration and reperfusion for $120 \mathrm{~min}$ (group F). The dose height selection criteria of Epo and U-74389G were assessed at preliminary studies as $10 \mathrm{mg} / \mathrm{kg}$ body mass of animals for both drugs.

The ischemia was caused by laparotomic clamping inferior aorta over the renal arteries with forceps for $45 \mathrm{~min}$. Reperfusion was induced by removing the clamp and restoration the inferior aorta patency. The drugs were administered at the time of reperfusion; through an inferior vena cava catheter. The creatinine levels were determined at 60th min of reperfusion (for A, C and E groups) and at 120th min of reperfusion (for $B, D$ and $F$ groups). The creatinine values used were adjusted for rats' mass since a powerful relation was invented between them $(p$-value $=0.0000)$.

\section{Statistical analysis}

-Table 1 presents the (\%) excretory superiority of Epo than placebo regarding reperfusion endpoints. Also, - Table 2 presents the (\%) excretory superiority of U-74389G than placebo regarding reperfusion endpoints. The chi-square tests were applied, in order the above superiorities to be compared; using the ratios which produced the (\%) results per endpoint. The outcomes of chi-square tests are depicted in - Table 3. The statistical analysis was performed by Stata 6.0 software (Stata 6.0, StataCorp LP, Texas, USA).

Table 1 The (\%) excretory influence of erythropoietin in connection with reperfusion time. Significant $p$-values when being $<0.05$

\begin{tabular}{|l|l|l|l|}
\hline Decrease & \pm SD & $\begin{array}{l}\text { Reperfusion } \\
\text { time }\end{array}$ & $p$-Values \\
\hline $0.10 \%$ & $\pm 9.78 \%$ & $1 \mathrm{~h}$ & 0.9904 \\
\hline $4.84 \%$ & $\pm 5.78 \%$ & $1.5 \mathrm{~h}$ & 0.3721 \\
\hline $9.59 \%$ & $\pm 7.74 \%$ & $2 \mathrm{~h}$ & 0.1509 \\
\hline$-4.84 \%$ & $\pm 5.78 \%$ & $\begin{array}{l}\text { Reperfusion } \\
\text { time }\end{array}$ & 0.3549 \\
\hline $2.62 \%$ & $\pm 3.49 \%$ & Interaction & 0.4430 \\
\hline
\end{tabular}

Table 2 The (\%) excretory influence of U-74389G in connection with reperfusion time. Significant $p$-values when being $<0.05$

\begin{tabular}{|l|l|l|l|}
\hline Decrease & \pm SD & $\begin{array}{l}\text { Reperfusion } \\
\text { time }\end{array}$ & $p$-Values \\
\hline $15.96 \%$ & $\pm 8.71 \%$ & $1 \mathrm{~h}$ & 0.0663 \\
\hline $21.02 \%$ & $\pm 5.06 \%$ & $1.5 \mathrm{~h}$ & 0.0001 \\
\hline $26.09 \%$ & $\pm 6.12 \%$ & $2 \mathrm{~h}$ & 0.0003 \\
\hline$-4.20 \%$ & $\pm 6.12 \%$ & $\begin{array}{l}\text { Reperfusion } \\
\text { time }\end{array}$ & 0.4103 \\
\hline $11.69 \%$ & $\pm 3.16 \%$ & Interaction & 0.0005 \\
\hline
\end{tabular}

Table 3 The U-74389G/erythropoietin excretory efficacies ratios on serum creatinine levels after chi-square tests application. Significant $p$-values when being $<0.05$

\begin{tabular}{|l|l|l|l|l|}
\hline Odds ratio & \multicolumn{2}{|l|}{ [95\% Conf. interval] } & $p$-Values & Endpoint \\
\hline 168.9034 & 164.4292 & 173.4992 & 0.0000 & $1 \mathrm{~h}$ \\
\hline 4.872332 & 4.865416 & 4.879259 & 0.0000 & $1.5 \mathrm{~h}$ \\
\hline 3.039572 & 3.029025 & 3.050157 & 0.0000 & $2 \mathrm{~h}$ \\
\hline 1.0262016 & 1.0243103 & 1.0280964 & 0.0000 & $\begin{array}{l}\text { Reperfusion } \\
\text { time }\end{array}$ \\
\hline 5.005523 & 4.996097 & 5.014967 & 0.0000 & Interaction \\
\hline
\end{tabular}

\section{Results}

The successive application of chi-square tests revealed that the excretory capacity of U-74389G was superior than that of Epo by 168.9034-fold [164.4292-173.4992] at $1 \mathrm{~h}$, by 4.872332 -fold [4.865416-4.879259] at $1.5 \mathrm{~h}$, by $3.039572-$ fold [3.029025-3.050157] at $2 \mathrm{~h}$, by 1.0262016-fold [1.0243103-1.0280964] without drugs and by 5.005523fold [4.996097-5.014967] whether all variables have been considered $(p$-value $=0.0000)$.

\section{Discussion}

The same authors reviewing ${ }^{2} 12$ clinical trials, found lukewarm, non-significant, confusing and inconsistent excretory results for serum creatinine levels. Furthermore, Elshiekh et al. documented decreased ${ }^{3}$ plasma creatinine levels after treatment with recombinant human Epo (rhEpo) $5000 \mathrm{IU} / \mathrm{kg}$ intraperitoneally (IP) administered $30 \mathrm{~min}$ before renal IR or ischemic preconditioning (IPC) in male Wistar rats. Cakiroglu et al. calculated ${ }^{4}$ a non-significant tendency of serum creatinine levels for renal function improvement; particularly after daily Epo application at a concentration of $500 \mathrm{U} / \mathrm{kg}$ shortly after renal $30 \mathrm{~min}$ IR in rats. Kalantzi et al. ${ }^{5}$ did not correlate serum creatinine levels with the two peaks of serum Epo levels although the serum creatinine levels reduction preceded the rise of Epo levels in patients after successful renal transplantation. Hernández-Navarrete et al. ${ }^{6}$ noticed stable serum creatinine levels and glomerular filtration at 
Table 4 A U-74389G/erythropoietin efficacies ratios meta-analysis on 2 hematologic variables ${ }^{22}$ Significant $p$-values when being $<0.05$

\begin{tabular}{|l|l|l|l|l|l|l|l|l|l|l|l|}
\hline Endpoint & $1 \mathrm{~h}$ & $p$-Value & $1.5 \mathrm{~h}$ & $\boldsymbol{p}$-Value & $\mathbf{2 ~ h}$ & $p$-Value & $\begin{array}{l}\text { Reperfusion } \\
\text { time }\end{array}$ & $p$-Value & Interaction & $p$-Value \\
\hline Variable & &
\end{tabular}

24 months in post-transplant patients underwent 52.3 months pre-transplant peritoneal dialysis. Gardner et al. used $^{7}$ plasma creatinine levels to predict histopathological injury at $2 \mathrm{~h}$ after renal $40-\mathrm{min} / 48-\mathrm{h} \mathrm{I} / \mathrm{R}$; on renoprotective administration of Epo (1000 iu/ $\mathrm{kg}$ IV) or remote IPC in a porcine model. Ahmadiasl et al. decreased creatinine levels after pre-treatment with Epo $(5000 \mathrm{U} / \mathrm{kg}, \quad \mathrm{IP})^{8}$ before $45 \mathrm{~min} / 24 \mathrm{~h}$ renal I/R in male Wistar Albino rats. Wu et al. estimated a blood protein/creatinine levels ratio decreased by helix B surface peptide (HBSP) $8 \mathrm{nmol} / \mathrm{kg}$ derived from Epo; 2 weeks ${ }^{9}$ after $45 \mathrm{~min} / 2$ week renal I/R in a rat model. Kim et al. showed no significant differences on the incidence of post-operative acute kidney injury (AKI) defined as an increase in serum creatinine $>0.3 \mathrm{mg} / \mathrm{dl}$ or $>50 \%$ from baseline after ${ }^{10}$ pre-emptive Epo administration $300 \mathrm{IU} / \mathrm{kg}$ IV in patients. Li et al. showed a modest effect in preventing lipopolysaccharide (LPS)-induced elevation of creatinine levels and protecting against injured ultrastructure in the kidneys $24 \mathrm{~h}$ after rhEpo treatment $(5000 \mathrm{U} / \mathrm{kg})^{11}$ in rats. Moeini et al. succeeded significantly decreased levels of creatinine $(p<0.05)$ after $^{12}$ Epo administration $(500 \mathrm{IU} / \mathrm{kg}$ IP) in AKI male Wistar rats. Han et al. attenuated the renal damage, the necrotic injury and the peak plasma creatinine levels ${ }^{13}$ after injection of mice adult renal progenitor cells (MRPC) which exhibit features consistent with renal stem cells; especially MRPC/Epo and MRPC/suramin in IR AKI male C57BL/6 mice. Matějková et al. found no differences after carbamylated Epo-FC fusion protein (cEpo-FC) $(50 \mu \mathrm{g} / \mathrm{kg}$ ), rhEpo (5000 IU/kg), or vehicle prior to $120 \mathrm{~min} / 4 \mathrm{~h} \mathrm{I} / \mathrm{R}$ injury between treatment groups in pigs with atherosclerosis. ${ }^{14}$ Ardalan et al. found ${ }^{15}$ lower creatinine levels in renal IR + Epo group than only renal IR group $(p<0.05)$ after renal $30 \mathrm{~min} / 24 \mathrm{~h} \mathrm{I} / \mathrm{R}$ in male Wistar rats. Ulusoy et al. found that creatinine significantly increased signal peptide-CUB (complement $\mathrm{C} 1 \mathrm{r} / \mathrm{C} 1 \mathrm{~s}$, Uegf, and Bmp1)-EGF (epidermal growth factor)-domain-containing protein 1 SCUBE1 levels ${ }^{16}$ higher in a HD group than a control $(p=0.000)$ one. Imamura et al. evaluated that cEpo and Epo-treated IR rats had improved serum creatinine levels than saline-treated remnant kidney IR model rats. ${ }^{17}$ Rodrigues et al. preserved creatinine clearance and tubular function after pretreatment with continuous Epo receptor activator (CERA) ${ }^{18}$ in a sepsis-induced AKI model. Oba et al. found that ${ }^{19}$ Epo administration significantly inhibited the increase in blood creatinine levels after renal IR injury than control mice. Hu et al. exhibited lower serum creatinine levels and limited tubular necrosis $24 \mathrm{~h}$ after Epo administration in induced renal IR of male Sprague-
Dawley rats. ${ }^{20}$ Chrysikos et al. did not find significantly different serum creatinine levels after U-74389G IV injection $^{21}$ after pancreatic IR encompassing IPC $30 \mathrm{~min} / 120 \mathrm{~min}$ in pigs.

According to above, - Table 4 shows that U-74389G has at least 5 -fold excretory capacity than Epo $(p$-value $=0.0000)$. A more detailed molecular and biochemical investigation of this excretory potency must be hold in order to elucidate the U-74389G molecular action mechanism.

\section{Conclusion}

The nephrologists and urologists must be informed about the effective excretory potencies of U-74389G when treat HD patients.

\section{Ethical disclosures}

\section{Protection of human and animal subjects}

The authors declare that the procedures followed were in accordance with the regulations of the relevant clinical research ethics committee and with those of the Code of Ethics of the World Medical Association (Declaration of Helsinki).

\section{Confidentiality of data}

The authors declare that no patient data appear in this article.

\section{Right to privacy and informed consent}

The authors declare that no patient data appear in this article.

Conflict of interests

The authors declare that they have no conflicts of interest.

\section{References}

1 Tsompos C, Panoulis C, Toutouzas K, Zografos G, Papalois A. The effect of the antioxidant drug U-74389G on creatinine levels during ischemia reperfusion injury in rats. Curr Urol 2015; 9:73-78

2 Tsompos C, Panoulis C, Toutouzas K, Zografos G, Papalois A. The effect of erythropoietin on creatinine levels during ischemia reperfusion injury in rats. Literati J Pharm Drug Deliv Technol 2015;1:1-6

3 Elshiekh M, Kadkhodaee M, Seifi B, Ranjbaran M, Ahghari P. Ameliorative effect of recombinant human erythropoietin and ischemic preconditioning on renal ischemia reperfusion injury in rats. Nephrourol Mon 2015;7:e31152 
4 Cakiroglu F, Enders-Comberg SM, Pagel H, Rohwedel J, Lehnert H, Kramer J. Erythropoietin-enhanced endothelial progenitor cell recruitment in peripheral blood and renal vessels during experimental acute kidney injury in rats. Cell Biol Int 2016;40:298-307

5 Kalantzi M, Kalliakmani P, Papachristou E, Papasotiriou M, Savvidaki E, Zavvos V, et al. Parameters influencing blood erythropoietin levels of renal transplant recipients during the early posttransplantation period. Transplant Proc 2014;46:3179-3182

6 Hernández-Navarrete LS, Hernández-Jiménez JD, Jiménez-López LA, Budar-Fernández LF, Méndez-López MT, Martínez-Mier G. Experience in kidney transplantation without blood transfusion: kidney transplantation transfusion-free in Jehovah's Witnesses. First communication in Mexico. Cir Cir 2013;81:450-453

7 Gardner DS, Welham SJ, Dunford LJ, McCulloch TA, Hodi Z, Sleeman $P$, et al. Remote conditioning or erythropoietin before surgery primes kidneys to clear ischemia-reperfusion-damaged cells: a renoprotective mechanism? Am J Physiology Renal Physiology 2014;306:F873-F884

8 Ahmadiasl N, Banaei S, Alihemmati A, Baradaran B, Azimian E. The anti-inflammatory effect of erythropoietin and melatonin on renal ischemia reperfusion injury in male rats. Adv Pharm Bull 2014;4:49-54

9 Wu Y, Zhang J, Liu F, Yang C, Zhang Y, Liu A, et al. Protective effects of HBSP on ischemia reperfusion and cyclosporine a induced renal injury. Clin Dev Immunol 2013;2013:758159

10 Kim JH, Shim JK, Song JW, Song Y, Kim HB, Kwak YL. Effect of erythropoietin on the incidence of acute kidney injury following complex valvular heart surgery: a double blind, randomized clinical trial of efficacy and safety. Crit Care 2013;17:R254

11 Li XJ, Zhang GX, Sun N, Sun Y, Yang LZ, Du YJ. Protective effects of erythropoietin on endotoxin-related organ injury in rats. J Huazhong Univ Sci Technol Med Sci 2013;33:680-686

12 Moeini M, Nematbakhsh M, Fazilati M, Talebi A, Pilehvarian AA, Azarkish F, et al. Protective role of recombinant human erythropoietin in kidney and lung injury following renal bilateral ischemia-reperfusion in rat model. Int J Prev Med 2013;4:648-655

13 Han X, Zhao L, Lu G, Ge J, Zhao Y, Zu S, et al. Improving outcomes of acute kidney injury using mouse renal progenitor cells alone or in combination with erythropoietin or suramin. Stem Cell Res Ther 2013;4:74

14 Matějková Š, Scheuerle A, Wagner F, McCook O, Matallo J, Gröger M, et al. Carbamylated erythropoietin-FC fusion protein and recombinant human erythropoietin during porcine kidney ischemia/reperfusion injury. Intensive Care Med 2013;39: 497-510

15 Ardalan MR, Estakhri R, Hajipour B, Ansarin K, Asl NA, Nasirizade MR, et al. Erythropoietin ameliorates oxidative stress and tissue injury following renal ischemia/reperfusion in rat kidney and lung. Med Princ Pract 2013;22:70-74

16 Ulusoy S, Ozkan G, Menteşe A, Yavuz A, Karahan SC, Sümer AU. Signal peptide-CUB-EGF domain-containing protein 1 (SCUBE1) level in hemodialysis patients and parameters affecting that level. Clin Biochem 2012;45:1444-1449

17 Imamura R, Isaka Y, Sandoval RM, Ichimaru N, Abe T, Okumi M, et al. A nonerythropoietic derivative of erythropoietin inhibits tubulointerstitial fibrosis in remnant kidney. Clin Exp Nephrol 2012;16:852-862

18 Rodrigues CE, Sanches TR, Volpini RA, Shimizu MH, Kuriki PS, Camara NO, et al. Effects of continuous erythropoietin receptor activator in sepsis-induced acute kidney injury and multi-organ dysfunction. PLoS ONE 2012;7:e29893

19 Oba S, Suzuki E, Nishimatsu H, Kumano S, Hosoda C, Homma Y, et al. Renoprotective effect of erythropoietin in ischemia/reperfusion injury: possible roles of the Akt/endothelial nitric oxide synthase-dependent pathway. Int J Urol 2012;19:248-255

20 Hu L, Yang C, Zhao T, Xu M, Tang Q Yang B, et al. Erythropoietin ameliorates renal ischemia and reperfusion injury via inhibiting tubulointerstitial inflammation. J Surg Res 2012;176:260-266

21 Chrysikos DT, Sergentanis TN, Zagouri F, Psaltopoulou T, Theodoropoulos G, Flessas I, et al. Lazaroid U-74389G administration in pancreatic ischemia-reperfusion injury: a swine model encompassing ischemic preconditioning. JOP 2015;16:176-184

22 Tsompos C, Panoulis C, Toutouzas K, Zografos G, Papalois A. Comparison of the acute erythropoietic capacities of erythropoietin and U-74389G concerning hemoglobin levels. Blood Res 2017; [in press] 